\title{
Cikkismertetés: Hatékony eszköz-e a pénzvisszatérítés egészséges élelmiszerek vásárlásának ösztönzésére?
}

\author{
Article review: Could be financial incentives an effective way to increase \\ healthy food purchases?
}

$\begin{array}{ll}\text { Ismertető: } & \text { Skerlecz Petra } \square \\ & \text { Pécsi Tudományegyetem, Általános Orvostudományi Kar, } \\ & \text { Orvosi Népegészségtani Intézet }\end{array}$

Ismertetett cikk: Gopalan A, Shaw PA, Lim R, et al. Use of financial incentives and text message feedback to increase healthy food purchases in a grocery store cash back program: a randomized controlled trial. BMC Public Health. 2019; 19(1):674. doi: 10.1186/s12889-019-6936-5.

Beküldve: $\quad$ 2019. 08. 07.

doi: $\quad$ 10.24365/ef.v60i5.503

Kulcsszavak: egészséges élelmiszer; anyagi ösztönzés; pénzvisszatérítés; személyre szabott információ

Keywords: healthy food; financial incentives; cash back; personalized information

Az egészséges táplálkozás sok ember számára jelentős kihívást jelent, mivel számos társadalmi, ökológiai és pszichés tényező jelenthet akadályt a megvalósításában; ilyen például az egészséges élelmiszerek magasabb ára, a táplálkozással kapcsolatos hiányos ismeretek, valamint az egészségtelen élelmiszerek elfogyasztásával társuló élvezetérzet. Korábbi tanulmányok kimutatták, hogy a különböző pénzügyi juttatások ösztönző hatásúak lehetnek az egészséges élelmiszerek vásárlására nézve, és azok a résztvevő́k, akik valamilyen anyagi kedvezményt kaptak, több gyümölcsöt és zöldséget vásároltak. $\mathrm{Az}$ anyagi tényezők mellett számos tanulmány bizonyította azt is, hogy az általános tudnivalókat tartalmazó üzenetekhez képest, a személyre szabott, egészséges táplálkozással kapcsolatos információk sokkal kedvezőbb hatást gyakoroltak az egyének étrenddel kapcsolatos viselkedésére. Egy dél-afrikai székhelyű egészségbiztosító, a Discovery összes tagja számára elérhető a „Vitality” névre hallgató, önkéntes, alacsony költségű wellness program, melynek célja a résztvevők egészségének javítása. Ennek egyik legnagyobb alegysége a "HealthyFood (HF) benefit”. A programban számos élelmiszerüzlet vesz részt, ha a tagok ezekben az üzletekben egészséges élelmiszereket vásárolnak (friss és fagyasztott zöldségek, gyümölcsök, teljes kiőrlésű gabonafélék, hüvelyesek, magvak stb.), a vásárlás összegéből 10\%-os pénzbeli visszatérítést és szöveges ösztönző üzeneteket kapnak.

A kutatás azon „Vitality”-programban részt vevő tagok között zajlott, akik a HF-tagságukat is aktiválták. A résztvevők két élelmiszerüzlet közül választhattak egyéni preferenciájuk alapján. A kutatók a boltokban található élelmiszereket három csoportba osztották: egészséges, egészségtelen, egyik sem. Az egészséges élelmiszereket „Vitality”matricával látták el, és a vásárlási bizonylatokon is külön jelölték. A vizsgálat elsődleges célja annak meghatározása volt, hogy az intervenciós időszak során átlagosan mennyi pénzt költenek a fogyasztók egészséges élelmiszerekre. Másodlagos célként az élelmiszerfogyasztási szokásokat szerették volna megfigyelni a kiválasztott üzletben, ide tartozott például az egészségtelen élelmiszerekre költött havi 
összeg és az egészségtelen, illetve egészséges élelmiszerek havonta vásárolt mennyiségének vizsgálata. A résztvevőket 6 intervenciós csoportba osztották. Az első csoportban lévők 10\% pénzvisszatérítést és havonta általános információkat tartalmazó üzeneteket kaptak. A második csoport tagjai szintén 10\% pénzvisszatérítést, heti és havi általános információkat tartalmazó üzeneteket kaptak. A harmadik csoportban lévők 10\% pénzvisszatérítésben, heti személyre szabott és havi általános információkat tartalmazó üzenetekben részesültek. A negyedik csoport részére már $25 \%$ pénzvisszatérítést, heti személyre szabott és havi általános információkat tartalmazó üzeneteket nyújtottak. Az ötödik csoport 10+15\% nettó pénzvisszatérítést és heti személyre szabott és havi általános információkat tartalmazó üzeneteket kapott. A hatodik csoportnak 10+15\% nettó pénzvisszatérítésről és heti személyre szabott és havi válogatott információkat tartalmazó üzeneteket biztosított a program. Az adatok elemzését Wilcoxon-féle próba segítségével végezték $(p=0,05)$.

A vizsgálatban összesen 2841 fő vett részt, őket egységesen osztották be a hat csoportba. A résztvevők 46,5\%-a nő volt, az átlagéletkor 47,8 111,8 év közé esett. Az intervenciós időszak alatt a legnagyobb különbség az 1-es és 2-es csoport vásárlási szokásai között mutatkozott, azonban ez a különbség nem volt szignifikáns. Az 1-es csoport tagjainak havi élelmiszervásárlásában átlagosan 24,8\%-ot az egészséges, míg 24,4\%-ot az egészségtelen élelmiszerek adtak. Ezzel szemben a 2-es csoportban az egészséges élelmiszerek aránya az összes élelmiszervásárlás arányából 26,8\% volt, az egészségtelen ételek 21,7\%-ot tettek ki. A többi csoport élelmiszervásárlási szokásai tekintetében nem volt lényeges különbség, és egyik csoport között sem találtak szignifikáns eltérést az intervenciós időszak során. Annak ellenére, hogy a szakirodalomban számos vizsgálat bizonyította már az anyagi ösztönző eszközök és a szöveges visszajelzések élelmiszervásárlási szokásokra gyakorolt pozitív hatását, jelen kutatás esetében ez mégsem mutatkozott meg. Ebből a kutatók arra következtettek, hogy nem elég csupán az anyagi vagy szöveges ösztönzés ahhoz, hogy a vásárlók élelmiszerfogyasztási szokásait megváltoztassuk. A problémát komplex módon kell megközelíteni, és a fent említett tényezők mellett nagyon fontos a vásárlói környezet megváltoztatása, és a személyes motivációk erősítése is.

\section{TANULSÁGOK A HAZAI SZAKEMBEREK SZÁMÁRA}

Hazánkban jelenleg sajnos nem müködik a kutatásban bemutatott rendszerhez hasonló, egészséges élelmiszervásárlásra ösztönző program, de mindenképpen érdemes a fent említett sémához hasonlatos szisztéma magyarországi adaptációját megfontolni. Első lépésként például a teljes kiőrlésű, magas rosttartalmú kenyerek és pékáruk, valamint a zöldségek és gyümölcsök bizonyos mennyiségű vásárlása után pontokat kaphatnának a vásárlók. A pontgyűjtő füzetekben vezetett, bizonyos mennyiségű pontot pedig egészséges táplálkozáshoz kapcsolódó ajándékokra, esetlegesen bizonyos levásárolható összegű kuponra lehetne beváltani. 